\title{
Evaluation of Recombinant Human Lactoferricin Culture as a Substitute for Antibiotic in Pig Starter Diets
}

\author{
J. W. Hong*, I. H. Kim*, I. H. Hwang**, J. H. Lee**, J. H. Kim***, \\ O. S. Kwon* and S. H. Lee* \\ Department of Animal Resource \& Sciences, Dankook University, Cheonan, 330-714, Korea* \\ Easy-Bio System, Inc., Seoul, 135-937, Korea** \\ Agribrands Purina Korea, Inc., Seoul, 135-280, Koera*** \\ 이유자돈사료에 항생제를 대체하기 위한 \\ 재조합 인간 락토페리신 컬처의 평가 \\ 홍종욱*.김인호*.황일환**.이지훈**.김지훈***.권오석*.이상환* \\ 단국대학교 동물자원과학과*, (주)이지바이오시스템**, (주)애그리브랜드 퓨리나 코리아***
}

\begin{abstract}
Sixty [(Duroc $\times$ Yorkshire $) \times$ Landrace $]$ pigs $(7.63 \pm 0.41 \mathrm{~kg}$ average body weight and $25-\mathrm{d}$ average age $)$ were used in a 20-d growth assay to determine the effect of dietary recombinant human lactoferricin culture (RHLC) supplementation on growth performance, digestibility and plasma IgG concentration in weaning pigs. Dietary treatments included 1) Negative control (NC : without antibiotic), 2) Positive control (PC : NC diet $+0.1 \%$ chlortetracycline), 3) RHLC0.3 (NC diet $+0.3 \%$ RHLC), 4) RHLC0.5 (NC diet $+0.5 \%$ RHLC). No differences were found among treatments in average daily gain $(\mathrm{P}>0.05)$. ADFI of pigs fed RHLC0.3 diet was higher than that of pigs fed $\mathrm{PC}$ diet $(\mathrm{P}<0.05)$. However, pigs fed RHLC0.5 diet had improved gain/feed compared to pigs fed PC diet. Pigs fed PC and RHLC diets showed significantly increased dry matter digestibility compared to pigs fed $\mathrm{NC}$ diet $(\mathrm{P}<0.05)$. There was no significant difference in plasma IgG concentrations $(\mathrm{P}>0.05)$. The supplementation of RHLC in starter pig diets appears to be an alternative to antibiotics.
\end{abstract}

(Key words : Recombinant human lactoferricin culture; Antibiotic-free diet; Pigs)

\section{I . INTRODUCTION}

Weaning is stressful for pigs because of the adjustment from a liquid to a dry diet. This transition may alter the digestive tract's microbes, resulting in less desirable microflora that cause poor performance and diarrhea (van de Ligt et al., 2002). Diarrhea in neonatal and postweaning pigs is a serious problem due to the trend towards large intensive herds and early weaning (at 14-21 days rather than 21-28 days of age). One of the most common causes of diarrhea is infection with enterotoxigenic Escherichia coli (ETEC) which is normally kept under control in

Corresponding author : Dr. I. H. Kim, Dept. of Animal Resource \& Sciences, Dankook University, Cheonan, 330-714, Korea, Tel : +82-41-550-3652, Fax : +82-41-553-1618, E-mail : inhokim@dankook.ac.kr 
the young pigs by passive immunity imparted by antibodies present in the milk. Early weaning has resulted in the removal of this protection and thereby has greatly increased the incidence of the disease. Also, ETEC 987P is the most common cause of diarrhea is pigs in chungnam province, Korea.

Control of intestinal pathogens has long been a goal of both livestock producer and microbiologist. Methods used to achieve this goal include addition of antibiotic to feed, acidification of drinking water, competitive exclusion of pathogens using probiotics and antimicrobial levels of minerals such as zinc oxide and copper sulfate. The most common method of repressing undesirable microbes has been the use of antibacterial agents. Recent interest has focused on nonantibiotic feed additions because of public concern over drug residue in meat products and development of antibiotic resistant pathogenic organisms (Kunin, 1993). A possible nonantibiotic additive for pig diets is active lactoferrin.

Lactoferrin is secreted by exocrine glands, such as the mammary, intestinal and salivary glands, and by neutrophils. It shows both direct and indirect antimicrobial action and anti-viral effects. The bacteriostatic effects of lactoferrin are usually attributed to its ability to bind environmental iron ion(Arnold et al., 1977; Reiter, 1978; Reiter, 1983). Also, lactoferrin has been shown to bind to the outer membrane of Gram-negative bacteria and it induces the release of lipopolysaccherides, leading ultimately to the destruction of these bacteria (Ellison et al., 1988; Ellison et al., 1990). Lactoferrin inhibits the growth of many Gram- positive and Gram-negative, as well as some species of mold and yeast.

We previously demonstrated the successful production of human lactoferricin using a recombinant Pichia pastoris expression system(Choi et al., 1999).

The purpose of this experiment was to examine recombinant human lactoferricin culture(RHLC) as a substitute for antibiotics in the diets of weaned pigs.

\section{П. MATERIALS AND METHODS}

\section{Animals and diets}

Sixty [(Duroc $\times$ Yorkshire $) \times$ Landrace] $\operatorname{pigs}(7.63 \pm$ $0.41 \mathrm{~kg}$ average body weight, $25-\mathrm{d}$ average age and 21-d weaning age) were used in a 20-d growth assay to determine the effects of RHLC on growth performance, digestibility and serum IgG concentration in weaning pigs. The pigs were blocked by weight and assigned to treatments based on sex. There were three pigs per pen and five pens per treatment. Dietary treatments included 1) NC (Negative control : without antibiotic), 2) PC (Positive control : NC diet + $0.1 \%$ Chlortetracycline), 3) RHLC0.3 (NC diet + $0.3 \%$ RHLC, Easy-Bio System, Inc., Korea) and 4) $\mathrm{RHLC} 0.5$ ( $\mathrm{NC}$ diet $+0.5 \%$ RHLC). $\mathrm{NC} \operatorname{diet}$ (Table 1) was corn-dried whey-SBM based without antibiotic and formulated to contain 3,450 $\mathrm{kcal} \mathrm{ME} / \mathrm{kg}, 22.30 \%$ of crude protein, $1.50 \%$ of lysine, $0.42 \%$ of methionine, $0.90 \%$ of calcium and $0.80 \%$ of phosphorus. The diets were fed in meal form and formulated to be in excess of NRC (1998) recommendations for all nutrients. Chromic oxide was added $(0.2 \%$ in the diet $)$ as an indigestible marker to allow digestibility determinations. On d 15 of experiment, fecal samples were collected from two pigs per pen by rectal massage, pooled within pen, dried and ground.

\section{Procedures}

Pigs were allowed to consume feed and water on an ad libitum basis from a two holes feeder and nipple waterer. The pigs and feeder were weighed on d 10 and 20 to allow calculation of ADG, ADFI and gain/feed.

On day 0 of the experiment, pigs were dosed 
Table 1. Formula and chemical composition of basal diet(as-fed basis)

\begin{tabular}{lc}
\hline \multicolumn{1}{c}{ Ingredients } & $\%$ \\
\hline \hline Corn & 36.53 \\
Dried whey & 25.00 \\
Soybean meal (CP 48\%) & 16.40 \\
Soy flour & 12.50 \\
Animal fat & 5.00 \\
Spray-dried blood meal & 1.75 \\
Tricalcium phosphate & 1.67 \\
Fish meal & 0.28 \\
Vitamin premix ${ }^{1)}$ & 0.25 \\
Mineral premix & 0.15 \\
L-lysine·HCl & 0.13 \\
DL-methionine & 0.09 \\
Antioxidant (Ethoxyquin 25\%) & 0.05 \\
Chromic oxide & 0.20
\end{tabular}

\begin{tabular}{lr}
\hline Chemical composition $^{4}$ & \\
ME, kcal/kg & 3,450 \\
Crude protein (\%) & 22.30 \\
Lysine (\%) & 1.50 \\
Calcium (\%) & 0.90 \\
Phosphorus (\%) & 0.80 \\
\hline
\end{tabular}

${ }^{1)}$ Provided per $\mathrm{kg}$ of complete diet : 20,000 IU of vitamin $\mathrm{A} ; 4,000$ IU of vitamin $\mathrm{D}_{3} ; 80$ IU of vitamin $\mathrm{E} ; 16 \mathrm{mg}$ of vitamin $\mathrm{K}_{3} ; 4 \mathrm{mg}$ of thiamine; $20 \mathrm{mg}$ of riboflavin; $6 \mathrm{mg}$ of pyridoxine; $0.08 \mathrm{mg}$ of vitamin $\mathrm{B}_{12} ; 120 \mathrm{mg}$ of niacin; $50 \mathrm{mg}$ of $\mathrm{Ca}-$ pantothenate; $2 \mathrm{mg}$ of folic acid and $0.08 \mathrm{mg}$ of biotin.

${ }^{2)}$ Provided per $\mathrm{kg}$ of complete diet : $140 \mathrm{mg}$ of $\mathrm{Cu}$; $179 \mathrm{mg}$ of $\mathrm{Zn} ; 12.5 \mathrm{mg}$ of $\mathrm{Mn} ; 0.5 \mathrm{mg}$ of $\mathrm{I} ; 0.25$ $\mathrm{mg}$ of $\mathrm{Co}$ and $0.4 \mathrm{mg}$ of Se.

${ }^{3)}$ Used as an indigestible marker.

${ }^{4)}$ Calculated value.

orally with $E$. coli $987 \mathrm{P}(1.0 \mathrm{ml} / \mathrm{dose} ; 1.2 \times 108 / \mathrm{ml})$. ETEC 987P bacteria was obtained from Escherichia Coli Reference Centre, Pennsylvania State University, USA.

\section{Laboratory and statistical analyses}

Feed and feces were analyzed for $\mathrm{DM}$ and $\mathrm{N}$ concentrations(AOAC, 1995). Chromium was determined by UV absorption spectrophotometry (Shimadzu, UV-1201, Japan) and apparent digesti- bilities of DM and $\mathrm{N}$ were calculated using the indirect-ratio method.

The concentration of IgG in the plasma was measured to investigate the effect of RHLC supplementation on immune system. Blood samples were collected via jugular vein into vacutainer tubes(Becton Dickinson Vacutainer Systems, Franklin Lakes, NJ) from four pigs in each treatment at the termination of the feeding trial. Blood samples were centrifuged at 2,000g for $30 \mathrm{~min}$. Plasma samples were taken and stored at $-20^{\circ} \mathrm{C}$ until analyses for IgG. Plasma $\mathrm{IgG}$ concentration was determined by $\operatorname{IgG} \mathrm{Kit}(\mathrm{Behr}-$ ing, Germany).

Statistical analyses were carried out to compare the means by Duncan's multiple range test (Duncan, 1955) using General Linear Model procedure of SAS(1996).

\section{RESULTS AND DISCUSSION}

The growth, feed intake and feed efficiency of pigs fed the experimental diets are presented in Table 2. For $\mathrm{d} 0$ to 10 , average daily feed intake(ADFI) of pigs fed RHLC0.3 diet was higher than that of pigs fed $\mathrm{PC} \operatorname{diet}(\mathrm{P}<0.05)$. However, pigs fed the RHLC0.5 diet had significantly improved gain/feed $\operatorname{ratios}(\mathrm{P}<0.05)$ compared to pigs fed PC diet. For d 10 to 20, ADFI and gain/feed of pigs fed RHLC0.3 diet was higher than those of pigs fed PC diet $(\mathrm{P}<0.05)$. Through entire experimental period, ADFI of pigs fed RHLC0.3 diet was higher than that of pigs fed $\mathrm{PC} \operatorname{diet}(\mathrm{P}<0.05)$. Pigs fed RHLC0.5 diet had improved gain/feed compared to pigs fed PC diet.

Digestibility of dry matter and nitrogen in pigs fed experimental diet are presented in Table 3. Pigs fed PC and RHLC diets had significantly increased in dry matter digestibility compared to pigs fed $\mathrm{NC} \operatorname{diet}(\mathrm{P}<0.05)$.

Plasma IgG concentration of pigs fed exper- 
Table 2. Effects of dietary recombinant human lactoferricin culture on growth performance in weaned pigs ${ }^{1)}$

\begin{tabular}{lccccc}
\hline \multicolumn{1}{c}{ Item } & $\mathrm{NC}^{2)}$ & \multicolumn{1}{c}{$\mathrm{PC}^{2)}$} & $\mathrm{RHLC}^{2} 3^{2)}$ & $\mathrm{RHLC}^{2} 5^{2)}$ & $\mathrm{SE}^{3)}$ \\
\hline \hline 0-10 days & & & & & \\
Average daily gain (g) & 243 & 282 & 328 & 351 & 31 \\
Average daily feed intake (g) & $401^{\mathrm{b}}$ & $398^{\mathrm{b}}$ & $459^{\mathrm{a}}$ & $410^{\mathrm{b}}$ & 21 \\
Gain/feed & $0.61^{\mathrm{c}}$ & $0.71^{\mathrm{b}}$ & $0.71^{\mathrm{b}}$ & $0.86^{\mathrm{a}}$ & 0.05 \\
10-20 days & & & & & \\
Average daily gain (g) & 472 & 487 & 565 & 514 & 33 \\
Average daily feed intake (g) & $734^{\mathrm{b}}$ & $761^{\mathrm{b}}$ & $803^{\mathrm{a}}$ & $769^{\mathrm{b}}$ & 26 \\
Gain/feed & $0.64^{\mathrm{b}}$ & $0.64^{\mathrm{b}}$ & $0.70^{\mathrm{a}}$ & $0.67^{\mathrm{ab}}$ & 0.02 \\
0-20 days & & & & & \\
Average daily gain (g) & 358 & 385 & 447 & 433 & 26 \\
Average daily feed intake (g) & $568^{\mathrm{b}}$ & $579^{\mathrm{b}}$ & $631^{\mathrm{a}}$ & $590^{\mathrm{b}}$ & 21 \\
Gain/feed & $0.63^{\mathrm{b}}$ & $0.67^{\mathrm{b}}$ & $0.71^{\mathrm{ab}}$ & $0.73^{\mathrm{a}}$ & 0.02 \\
\hline
\end{tabular}

${ }^{1)}$ Sixty pigs with an average initial body weight of $7.63 \oplus 0.41 \mathrm{~kg}(\mathrm{SD})$.

${ }^{2)}$ Abbreviated NC, negative control added not antibiotic; PC, positive control added antibiotic; RHLC0.3, added $0.3 \%$ of recombinant human lactoferricin culture; RHLC 0.5 , added $0.5 \%$ of recombinant human lactoferricin culture.

${ }^{3}$ Pooled standard error.

${ }^{a b c}$ Means in the same row with different superscripts differ significantly $(\mathrm{P}<0.05)$.

Table 3. Effects of dietary recombinant human lactoferricin culture on nutrient digestibility and plasma $\operatorname{lgG}$ concentration in weaned pigs ${ }^{1)}$

\begin{tabular}{lccccc}
\hline \multicolumn{1}{c}{ Item } & $\mathrm{NC}^{2)}$ & $\mathrm{PC}^{2)}$ & $\mathrm{RHLC} 0.3^{2)}$ & $\mathrm{RHLC}^{2} 5^{2)}$ & $\mathrm{SE}^{3)}$ \\
\hline \hline Dry matter (\%) & $82.02^{\mathrm{b}}$ & $85.69^{\mathrm{a}}$ & $87.08^{\mathrm{a}}$ & $83.57^{\mathrm{a}}$ & 0.35 \\
Nitrogen (\%) & 81.62 & 83.69 & 85.80 & 83.21 & 0.43 \\
& & & & \\
Plasma IgG ( mg/dL) & 352.8 & 430.7 & 468.1 & 355.9 & 48.9 \\
\hline
\end{tabular}

${ }^{1)}$ Sixty pigs with an average initial body weight of $7.63 \oplus 0.41 \mathrm{~kg}(\mathrm{SD})$.

${ }^{2)}$ Abbreviated NC, negative control added not antibiotic; PC, positive control added antibiotic; RHLC0.3, added $0.3 \%$ of recombinant human lactoferricin culture; RHLC 0.5 , added $0.5 \%$ of recombinant human lactoferricin culture.

${ }^{3)}$ Pooled standard error.

${ }^{\text {ab }}$ Means in the same row with different superscripts differ significantly $(\mathrm{P}<0.05)$.

imental diets are presented in Table 3. There was no significant difference in $\operatorname{IgG}$ concentrations of plasma $(\mathrm{P}>0.05)$. The conclusion of RHLC in starter pig diets appears to be a viable alternative to antibiotics.

Lactoferrin is an iron-binding protein found in human mucosal secretions as well as the spe- cific granules of polymorphonuclear leukocytes. A variety of functions have been ascribed to the protein and proposed for lactoferrin included protection against microbial infections(Spik et al., 1978; Nemet and Simonovits, 1985; Ellison and Giehl, 1991; Yamauchi et al., 1993), regulation of immune function(Crouch et al., 1992; Machnicki 
et al., 1993), regulation of myelopoiesis (Sawatzki and Rich, 1989; Hangoc et al., 1991), cellular growth promotion (Nichols et al., 1987; Nichols et al., 1990), regulation of intestinal iron absorption (Davidson and Lonnerdal, 1989; Iyer and Lonnerdal, 1993) and regulation of transcription (Penco et al., 1995; He and Furmanski, 1995).

Bacteriostatic effects of lactoferrin are usually attributed to its ability to bind environmental iron ions. This protein inhibits the growth of many Gram-positive and Gram-negative bacteria, as well as some species of mold and yeast. Aguila et al. (2001) demonstrated that therapeutic approaches based on the use of ferrochelating agents such as lactoferrin combined with antimicrobial drugs may help to counteract the reduced efficacy of current antibiotics. Lee et al. (1998) evaluated the ability of lactoferring to protect germ free, colostrumsdeprived piglets against a lethal intravenous challenge with endotoxin ; it was shown that prefeeding with lactoferrin resulted in a significant decrease in piglet mortality compared to feeding with bovine serum albumin. The current study demonstrates that RHLC improves the feed efficiency of piglets fed antibiotic-free diets.

\section{SUMMARY}

개시시 체중 $7.63 \oplus 0.41 \mathrm{~kg}, 3$ 원 교잡종 이유 자돈(25일령) 60 두를 공시하여, 이유자돈 사료 내 재조합 인간 락토페리신 컬처(RHLC ; recombinant human lactoferricin culture)의 급여가 성장, 영양소 소화율 및 혈장내 면역글로블린 $\mathrm{G}$ 농도에 미치는 영향을 평가하기 위하여 20 일간 사양시험을 실시하였다. 시험설계는 1) 항 생제 무첨가구 $(\mathrm{NC}), 2)$ 항생제 첨가구 $(\mathrm{PC} ; \mathrm{NC}$ 사료 $+0.1 \%$ chlortetracycline), 3) 항생제 무첨 가구 사료에 $\mathrm{RHLC}$ 를 $0.3 \%$ 첨가한 처리구 (RHLC0.3; NC 사료 $+0.3 \%$ RHLC), 4) 항생제 무첨가구 사료에 $\mathrm{RHLC}$ 를 $0.5 \%$ 첨가한 처리구 (RHLC0.5; NC 사료 $+0.5 \%$ RHLC)로 4 개 처리 로 하였다. 총 사양시험 기간동안, 일당증체량 에 있어서는 항생제 첨가구와 비교하여 RHLC
의 첨가수준이 증가함에 따라 높아지는 경향을 보였으나, 표준오차가 크기 때문에 유의적인 차이는 보이지 않았다. 일당사료섭취량에 있어 서는 PC 처리구와 비교하여 RHLC0.3 처리구가 유의적으로 높았으며 $(\mathrm{P}<0.05)$, 사료효율에 있어 서는 PC 처리구와 비교하여 RHLC0.5 처리구가 가장 좋은 것으로 나타났다 $(\mathrm{P}<0.05)$. 영양소 소 화율에 있어서는 $\mathrm{NC}$ 처리구와 비교하여 $\mathrm{PC}$, $\mathrm{RHLC} 0.3$ 및 $\mathrm{RHLC} 0.5$ 처리구가 유의적으로 높 게 평가되었으며 $(\mathrm{P}<0.05)$, 혈장내 면역글로블린 $\mathrm{G}$ 농도는 처리구간에 유의적인 차이를 보이지 않았다. 결론적으로, 이유자돈에 있어 재조합 인간 락토페린신 컬처가 항생제를 대체할 가능 성이 있는 것으로 사료된다.

\section{REFERENCES}

1. Aguila, A., Herrera, A. G., Morrison, D., Cosgrove, B., Perojo, A., Montesinos, I., Pérez, J., Sierra, G., Gemmell, C. G. and Brock, J. H. 2001. Bacteriostatic activity of human lactoferrin against Staphylococcus aureus is a function of its iron-binding properties and is not influenced by antibiotic resistance. FEMS Immun. Med. Microbiol. 31:145-152.

2. AOAC. 1995. Official method of analysis. 16th Edition. Association of Official Analytical Chemists, Washington, DC.

3. Arnold, R. R., Cole, M. F. and McGhee, J. R. 1977. A bactericidal effect for human lactoferrin. Science. 197:263-265.

4. Choi, Y. J., Moon, T. H., Sung, C. G., Bok, J. D., Shin, M. S., Yang, J. C., Joo, I. S. and Woo, M. S. 1999. Kor. Patent 1019990045291.

5. Crouch, S. P., Slater, K. J. and Fletcher, J. 1992. Regulation of cytokine release from mononuclear cells by the iron-binding protein lactoferrin. Blood. 80:235-240.

6. Davidson, L. A. and Lonnerdal, B. 1989. Fe-saturation and proteolysis of human lactoferrin: effect on brushborder receptor-mediated uptake of $\mathrm{Fe}$ and $\mathrm{Mn}$. Am. J. Physiol. 257:930-934.

7. Duncan, D. B. 1955. Multiple range and multiple F tests. Biometrics. 11, 1.

8. Ellison, R. T., Giehl, T. J. and LaForce, F. M. 1988. Damage of the outer membrane of enteric gram-negative bacteria by lactoferrin and transferrin. Infect. Immun. 56:2774-2781.

9. Ellison, R. T., LaForce, F. M., Giehl, T. J., Boose, D. S. and Dunn, B. E. 1990. Lactoferrin and trans- 
ferrin damage of the gram-negative outer membrane is modulated by $\mathrm{Ca}^{2+}$ and $\mathrm{Mg}^{2+}$. J. Gen. Microbiol. 136:1437-1446.

10. Ellison, R. T. and Giehl, T. J. 1991. Killing of gramnegative bacteria by lactoferrin and lysozyme. J. Clin. Invest. 88:1080-1091.

11. Hangoc, G., Falkenburg, J. H. and Broxmeyer, H. E. 1991. Influence of T-lymphocytes and lactoferrin on the survival-promoting effects of IL-1 and IL-6 on human bone marrow granulocyte-macrophage and erythroid progenitor cells. Exp. Hematol. 19:697-703.

12. He, J. and Furmanski, P. 1995. Sequence specificity and transcriptional activation in the binding of lactoferrin to DNA. Nature. 373:721-724.

13. Iyer, S. and Lonnerdal, B. 1993. Lactoferrin, lactoferrin receptors and iron metabolism. Eur. J. Clin. Nutr. 47:232-241.

14. Kunin, C. M. 1993. Resistance to antimicrobial drugs. Ann. Intern. Med. 118:557-561.

15. Lee, W. J., Farmer, J. L., Hilty, M. and Kim, Y. B. 1998. The protective effects of lactoferrin feeding against endotoxin lethal shock in germfree piglets. Infect. Immun. 66:1421-1426.

16. Machnicki, M., Zimecki, M. and Zagulski, T. 1993. Lactoferrin regulates the release of tumour necrosis factor alpha and interleukin 6 in vivo. Int. J. Exp. Pathol. 74:433-439.

17. Nemet, K. and Simonovits, I. 1985. The biological role of lactoferrin. Haematologia. 18:3-12.

18. Nichols, B. L., McKee, K. S. and Huebers, H. A. 1990. Iron is not required in the lactoferrin stimulation of thymidine incorporation into the DNA of rat crypt enterocytes. Pediatr. Res. 27:525-528.

19. Nichols, B. L., McKee, K. S., Henry, J. F. and
Putman, M. 1987. Human lactoferrin stimulates thymidine incorporation into DNA of rat crypt cells. Pediatr. Res. 21:563-567.

20. National Research Council. 1998. Nutrient Requirements of Swine. 10th Edition. National Academy Press, Washington, DC.

21. Penco, S., Pastorino, S., Bianchi-Scarra, G.. and Garre, C. 1995. Lactoferrin down-modulates the activity of the granulocyte macrophage colonystimulating factor promoter in interleukin-1 betastimulated cells. J. Biol. Chem. 270:12263-12268.

22. Reiter, B. 1978. Review of nonspecific antimicrobial factors in colostrums. Ann. Rech. Vet. 9:205-224.

23. Reiter, B. 1983. The biological significance of lactoferrin. Int. J. Tissue React. 5:87-96.

24. SAS. 1996. SAS user's guide. Release 6.12 edition. SAS Institute. Inc., Cary, NC.

25. Sawatzki, G.. and Rich, I. N. 1989. Lactoferrin stimulates colony stimulating factor production in vitro and in vivo. Blood Cells. 15:371-385.

26. Spik, G., Cheron, A., Montreuil, J. and Dolby, J. M. 1978. Bacteriostasis of a milk-sensitive strain of Escherichia coli by immunoglobulins and iron-binding proteins in association. Immunology. 35:663-671.

27. van de Ligt, J. L. G., Lindemann, M. D., Harmon, R. J., Monegue, H. J. and Cromwell, G. L. 2002. Effect of chromium tripicolinate supplementation on porcine immune response during the periparturient and neonatal period. Anim. Sci. 80:456-466.

28. Yamauchi, K., Tomita, M., Giehl, T. J. and Ellison, R. T. 1993. Antibacterial activity of lactoferrin and a pepsin-derived lactoferrin peptide fragment. Infect. Immun. 61:719-728.

(접수일자 : 2003. 2. 12. / 채택일자 : 2003. 4. 30.) 